\title{
Synthesis, Characterizations and Antimicrobial Activity of Cuprous Oxide $\left(\mathrm{Cu}_{2} \mathrm{O}\right)$ Nanoparticles
}

\author{
Amrit Regmi ${ }^{1}$, Janak Bhandari', Sitaram Bhattarai ${ }^{2}$, Surendra K. Gautam ${ }^{1 *}$ \\ ${ }^{1}$ Department of Chemistry, Tri-Chandra Multiple Campus, Tribhuvan University, Kathmandu, Nepal \\ ${ }^{2}$ Center for Nanomaterials, Sogang University, Seoul, South Korea \\ *Corresponding E-mail: sgautam2055@yahoo.com \\ (Received: Sept. 17, 2019; Revised: Dec. 23, 2019 \& Accepted: Dec. 24, 2019)
}

\begin{abstract}
Cuprous oxide nanoparticles were synthesized by the reduction of copper sulphate pentahydrate salt at different concentration using sodium borohydride as a reducing agent, polyethylene glycol-6000 as a stabilizer by simple, chemical co-precipitation methods and the effect of concentration on particle size were also studied. The crystalline size and phase of $\mathrm{Cu}_{2} \mathrm{O}$ nanoparticles (NPs) were authenticated by X-ray diffraction (XRD), morphology and structure by scanning electron microscopy (SEM), transmission electron microscopy (TEM), and elemental analysis was carried out by energy-dispersive X-ray spectroscopy (EDX). The concentrationdependent antimicrobial properties of $\mathrm{Cu}_{2} \mathrm{O}$ NPs were studied for a different strain of bacteria. XRD and selected area electron diffraction studies (SAED) patterns confirmed the formation of face-centered-cubic $\mathrm{Cu}_{2} \mathrm{O}$ nanoparticles with size $4.77 \mathrm{~nm}$ and $8.02 \mathrm{~nm}$ at two different concentrations of $0.01 \mathrm{M}$ and $0.1 \mathrm{M} \mathrm{CuSO}_{4}$, respectively. SEM and TEM images showed that the nanoparticles were uniform, in the form of clusters, and homogeneously distributed. EDX confirmed that synthesized nanoparticles were in pure form having copper and oxygen ratio $3: 1$ based on the atomic percentage of the chemical species. $\mathrm{Cu}_{2} \mathrm{O}$ nanoparticles showed excellent antibacterial activity against both bacterial strains Gram-positive (Staphylococcus aureus) and Gram-negative (Escherichia coli). The antibacterial activities of $\mathrm{Cu}_{2} \mathrm{O}$ NPs were found to be concentrationdependents and large bactericidal effect were seen for Gram-positive (Staphylococcus aureus) bacteria at higher concentrations of $\mathrm{Cu}_{2} \mathrm{O}$ NPs.
\end{abstract}

Keywords: Bactericidal, co-precipitation, EDX, Gram-positive, XRD

\section{Introduction}

P-type semiconductor [1] $\mathrm{Cu}_{2} \mathrm{O}$ NPs have gained huge attention in scientific society due to captivating properties such as high critical temperature superconductors [1], direct bandgap of $2.2 \mathrm{eV}$ [2], antimicrobial activity [1], low toxicity [3], photocatalytic activity [4], low cost and most abundant source materials [2], etc. Because of such practically applicable properties, $\mathrm{Cu}_{2} \mathrm{O}$ nanoparticles have been broadly studied in the various application fields like batteries [1], catalysis [5], gas sensor, biosensors [2], magnetic storage devices [6], medical, antifouling coating [6], photo $\neg$ voltaic and photocatalytic degradation of most of the organic pollutants $[3,7]$.

$\mathrm{Cu}_{2} \mathrm{O}$ nanoparticles have excellent optical, physical, electrical, magnetic, and biological properties compared to the bulk and microparticles because of the large surface area to volume ratio $[4,8]$. These novel properties are strongly related to the synthetic processes [4] and there are numerous synthesis techniques like mechanical milling, vacuum vapor deposition, pulsed laser ablation, and pulsed wire discharge, microemulsion techniques, wet-chemistry route, electrochemical, sonochemical, microwaveassisted, thermal decomposition and hydrothermal methods, liquid hydrolysis, etc [1-8]. Among all those synthesizes methods, chemical co-precipitation method is superior because of following advantages as it can be performed even in room temperature and pressure, it is inexpensive, and also not required specialized equipment and organic solvents in the 
reaction [9].

The metal nanoparticles such as $\mathrm{Ag}, \mathrm{Cu}$, etc. are found to have antibacterial activity $[9,10]$. The antibacterial effect of copper nanoparticles has been credited to their small size and high surface to volume ratio which allows them to interact closely with microbial membranes [11]. Although the mechanisms behind the antimicrobial activity of copper nanoparticles are still mystified, the most accepted hypothetical mechanisms, first pileup, and dissolution of nanoparticles in the bacterial membrane changing its permeability causes the degeneracy of the proton motive force across the plasma membrane, and successive discharge of lipo-polysaccharides, intracellular biomolecules, membrane proteins $[12,13]$ and next is uptake of metallic ions derived from NPs or entirely NPs into cells, causing depletion of intracellular ATP production and disruption of DNA replication $[14,15]$.

\section{Materials and Methods}

\section{a. Synthesis of $\mathrm{Cu}_{2} \mathrm{O}$ nanoparticles}

Chemicals like copper sulphate pentahydrate salt $\left(\mathrm{CuSO}_{4} .5 \mathrm{H}_{2} \mathrm{O}\right)$, polyethylene glycol-6000 (PEG6000), were obtained from Merck, sodium borohydride (NaBH4) was obtained from Sigma-Aldrich, and all chemicals were laboratory grade of reagent and used directly to synthesize $\mathrm{Cu}_{2} \mathrm{O}$ nanoparticles by coprecipitation method without further purification.

$0.01 \mathrm{M}$ and $0.1 \mathrm{M}$ solution of $\mathrm{CuSO}_{4} \cdot 5 \mathrm{H}_{2} \mathrm{O}$ were prepared using double ionized water, PEG-6000 were added and magnetically stirred for half an hour. After that $0.1 \mathrm{M} \mathrm{NaBH}_{4}$ solutions were added drop by drop till the color of the solution changed to black. The black color of the solution indicates the start of the reduction reaction; the solution was further magnetically stirred for one hour and left overnight for aging. Dry particles of $\mathrm{Cu}_{2} \mathrm{O}$ nanoparticles were obtained in the Whatman filter paper after filtering the aging solution.

\section{b. Characterization techniques}

The average particle size and surface morphology of the $\mathrm{Cu}_{2} \mathrm{O}$ were estimated by TEM images (Tecnai $\mathrm{G}^{2}$ 20 electron microscope) and SEM image (JEOL model JSM-7600F) whereas the elemental compositions (purity) of the synthesized nanoparticles were studied by EDX (JEOL model JSM-7600F). Crystalline size and crystallite structure of $\mathrm{Cu}_{2} \mathrm{O}$ nanoparticles were determined by XRD (Rigaku ultima IV model) employing $\mathrm{CuK} \alpha$ radiation $(\lambda=0.15406 \mathrm{~nm})$. The average crystallite size " $D$ " of nanoparticles was calculated using Debye-Scherrer's equation:

$\mathrm{D}=0.94 \lambda / \beta \operatorname{Cos} \theta$

Where, $\lambda$ is the $\mathrm{X}$-ray wavelength $(0.15406 \mathrm{~nm}), \beta$ is the full width at half maximum in radian and $\theta$ is the Bragg's diffraction angle.

\section{c. Antimicrobial activity of $\mathrm{Cu}_{2} \mathrm{O}$ nanoparticles}

Two bacterial strains, namely Staphylococcus aureus and Escherichia coli a Gram-positive and Gramnegative bacteria respectively, were taken from the Central Department of Biotechnology, Tribhuvan University, and were grown in LB Agar (Luria Bertani) and stored at $4^{\circ} \mathrm{C}$. The media plates were made of Muller Hinton Agar (MHA). Bacterial lawn cultures were prepared by taking the respective bacteria for the different Petri plates labeled accordingly with the help of a cotton swab.

$10 \mathrm{mg}$ per mL stock solution of the synthesized $\mathrm{Cu}_{2} \mathrm{O}$ NPs synthesized using $0.01 \mathrm{M} \mathrm{CuSO}_{4}$ solutions were taken and diluted to $(0.1,0.5,0.75$ and 1$) \mathrm{mg}$ per $\mathrm{mL}$ in dimethyl sulfoxide (DMSO) and was also used as a negative control sample. $50 \mu \mathrm{L}$ of each sample solution was introduced very carefully in the wells of labeled Petri plates, respectively with the help of micropipette and were left for a while to diffuse the sample through Media. Finally, these plates were incubated at $37{ }^{\circ} \mathrm{C}$ for $24 \mathrm{hrs}$.

\section{Results and Discussion}

\section{i. Crystalline analysis}

XRD data of the synthesized $\mathrm{Cu}_{2} \mathrm{O}$ nanoparticles were plotted in figure 1 from $25^{\circ}$ to $80^{\circ}$ which revealed the structures were crystalline. In figure 1 , there are six distinct peaks appearing at $2 \Theta$ values of $29.68^{\circ}$, $36.68^{\circ}, 42.6^{\circ}, 61.76^{\circ}, 73.98^{\circ}$ and $77.8^{\circ}$ corresponding to the hkl values (110), (111), (200), (220), (311) and (222), respectively and peaks also matches with the (JCPDS 05-669) reference standard XRD spectrum of $\mathrm{Cu}_{2} \mathrm{O}$ NPs [1]. Besides, no extra peaks of impurity are detected, indicating the synthesized $\mathrm{Cu}_{2} \mathrm{O}$ nanoparticles are pure, crystalline with cubic crystal structures. The average crystalline size of $\mathrm{Cu}_{2} \mathrm{O}$ nanoparticles was calculated from the most intense peak labeled 111 at $36.44^{\circ}$ using Debye- 
Scherrer's equation and was found to be $4.77 \mathrm{~nm}$ and $8.02 \mathrm{~nm}, 0.01 \mathrm{M}$ and $0.1 \mathrm{M}$ precursor concentrations, respectively. As the concentration of precursor increases, the hydrodynamic size of particles also increases. When the concentration of $\mathrm{CuSO}_{4} \cdot 5 \mathrm{H}_{2} \mathrm{O}$ increases, the stabilizer finds difficulty in fully covering the particles and consequently increases the part of the uncovered area of nanoparticles, which elevates the tendency of particles to interact with each other [16]. So, crystal sizes of $\mathrm{Cu}_{2} \mathrm{O}$ were found more significant at higher concentrations.

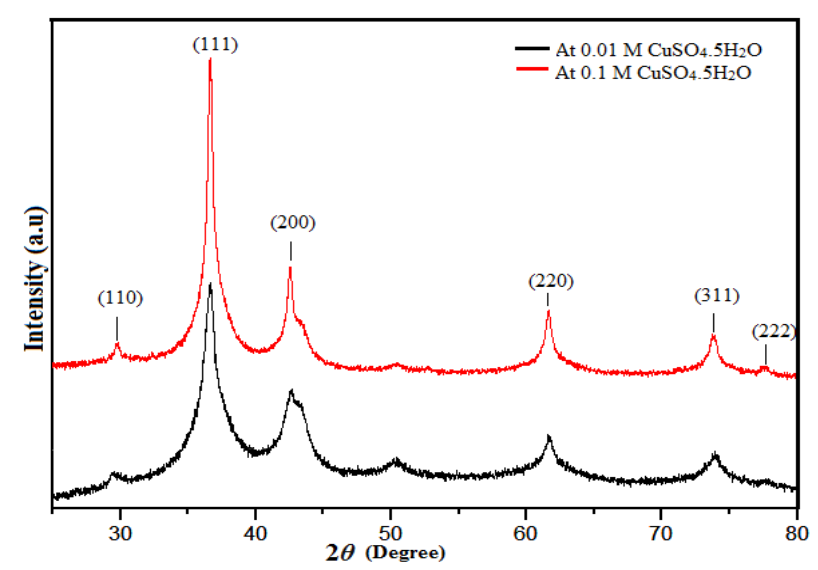

Figure 1: $X R D$ patterns of $\mathrm{Cu}_{2} \mathrm{O} N P S$ synthesized using two different concentration (a) $0.01 \mathrm{M}$ and (b) $0.1 \mathrm{M} \mathrm{CuSO}_{4}$ and reducing agent $\mathrm{NaBH}_{4}$.

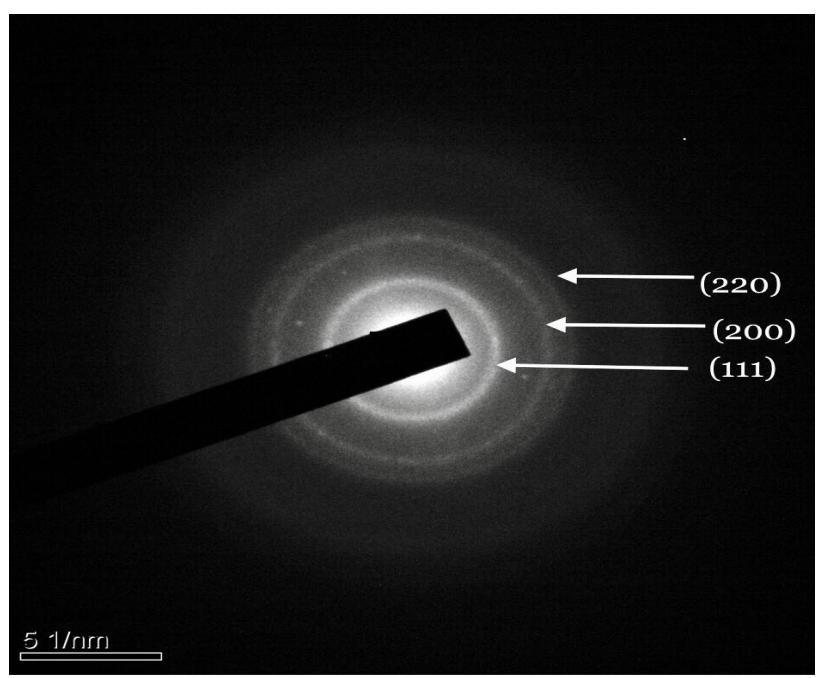

Figure 2: $\mathrm{SAED}$ pattern of $\mathrm{Cu}_{2} \mathrm{O} N \mathrm{NP}_{\mathrm{S}}$ synthesized using $0.01 \mathrm{M} \mathrm{CuSO}_{4}$ and reducing agent $\mathrm{NaBH}_{4}$.
The SAED patterns of the $\mathrm{Cu}_{2} \mathrm{O}$ NPs in figure 2 shows the characteristic diffraction rings corresponding to (111), (200) and (220) of the face-centered-cubic (FCC) phase which also well supported the crystalline phase obtained from XRD.

\section{ii Morphology analyses}

Scanning electron microscopy (SEM) and transmission electron microscopy (TEM) images of synthesized $\mathrm{Cu}_{2} \mathrm{O}$ nanoparticles using the precursor of $0.01 \mathrm{M} \mathrm{CuSO}_{4} .5 \mathrm{H}_{2} \mathrm{O}$ solution is shown in figures 3 and 4 , respectively.

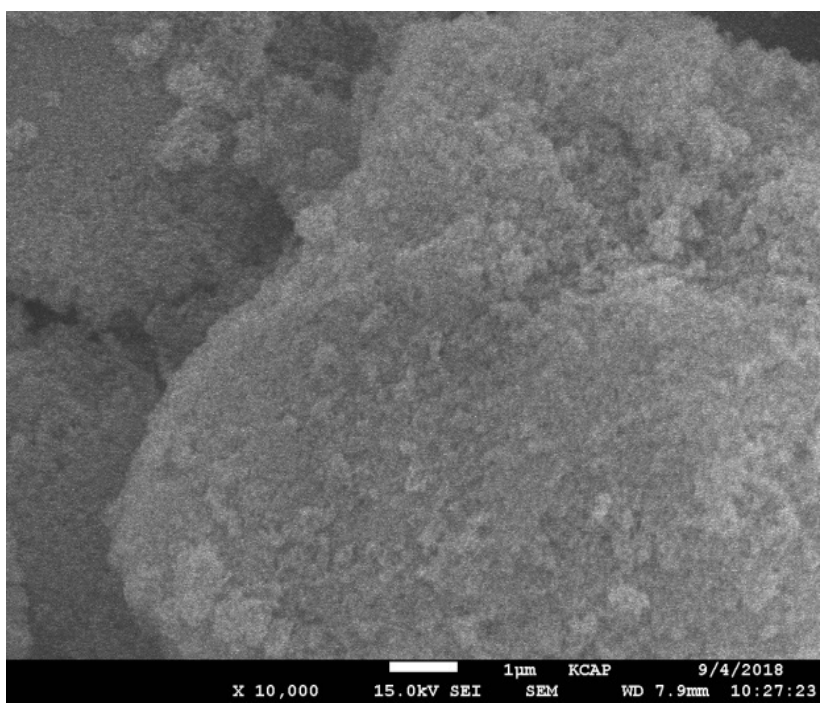

Figure 3: SEM image of $\mathrm{Cu}_{2} \mathrm{O}$ NPS synthesized using 0.01 $\mathrm{MCuSO}_{4}$ and reducing agent $\mathrm{NaBH}_{4}$

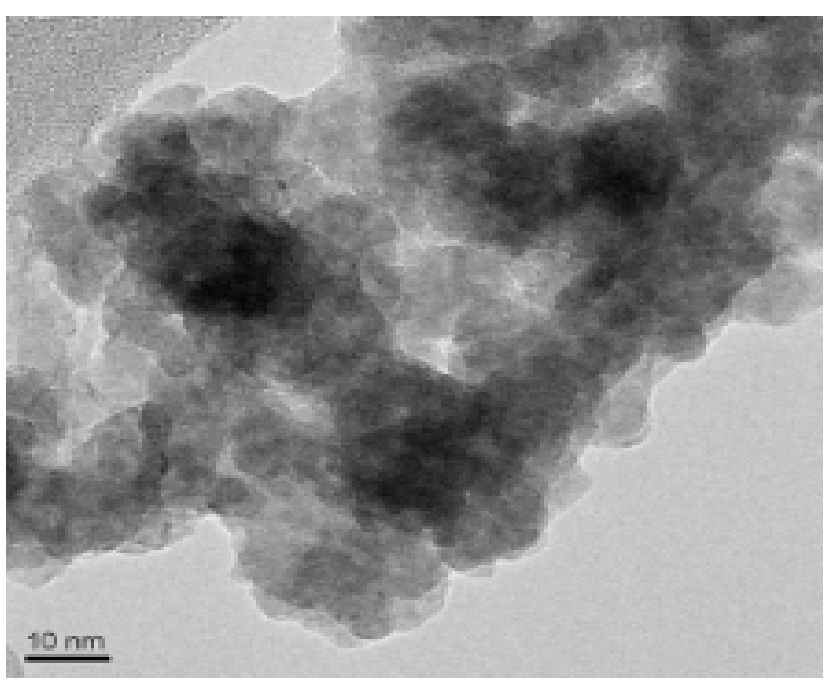

Figure 4: TEM image $\mathrm{Cu}_{2} \mathrm{O}$ NPS synthesized using 0.01 $\mathrm{MCuSO}_{4}$ and reducing agent $\mathrm{NaBH}_{4}$ 
SEM and TEM images reveal that the primary particles aggregate into secondary particles because of their small dimensions and high surface energy called Ostwald ripening process [17]. The images show that all NPs are uniform in size, in clusters form, homogeneously, and evenly distributed.

\section{iii Elemental analyses}

The EDX curve in figure 5 reveal the presence of copper, oxygen, carbon, and platinum as major elements and found in the sample $60.93 \%, 20.34$ $\%, 5.68 \%$, and $4.59 \%$, respectively on the basis of atomic percentage of the chemical species and also other trace elemental impurities such as aluminum, silicon, sulphur, zinc, and zirconium. Pure and stable copper oxide nanoparticles are formed with copper

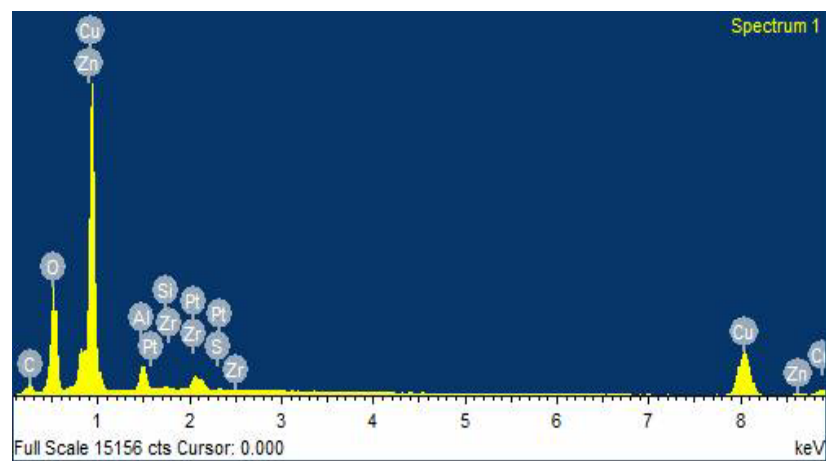

Figure 5: $\mathrm{EDX}$ of $\mathrm{Cu}_{2} \mathrm{O} N P S$ synthesized using $0.01 \mathrm{M}$ $\mathrm{CuSO}_{4}$ and reducing agent $\mathrm{NaBH}_{4}$

and oxygen in the ratio of 3:1 by atomic percentage. Impurities like platinum were recorded because samples were coated by platinum to prevent the sample from charging during the sample analysis, a recognizable amount of carbons were present in samples because polyethylene glycol-6000 were used as a stabilizing agent during $\mathrm{Cu}_{2} \mathrm{O}$ NPs synthesis and other impurities are due to the laboratory-grade of reagent used without further purification.

\section{iv Antibacterial analyses}

The antibacterial activities of synthesized $\mathrm{Cu}_{2} \mathrm{O}$ nanoparticles using the precursor of $0.01 \mathrm{M}$ $\mathrm{CuSO}_{4} \cdot 5 \mathrm{H}_{2} \mathrm{O}$ solution were screened with one Gramnegative (Escherichia coli) and one Gram-positive (Staphylococcus aureus) bacteria are shown in figures 6 and 7, respectively. The zones of inhibition of the $\mathrm{Cu}_{2} \mathrm{O}$ NPs at different concentration and standard tetracycline antibiotics were measured for both
Gram-positive and Gram-negative bacteria were summarized in table 1 . The antimicrobial properties of copper oxide mainly depend on the release of $\mathrm{Cu}^{+}, \mathrm{Cu}^{2+}$ ions and also on radicals like $\cdot \mathrm{OH}$, and $\mathrm{O}^{2--}$ generated from photocatalysis activity. These

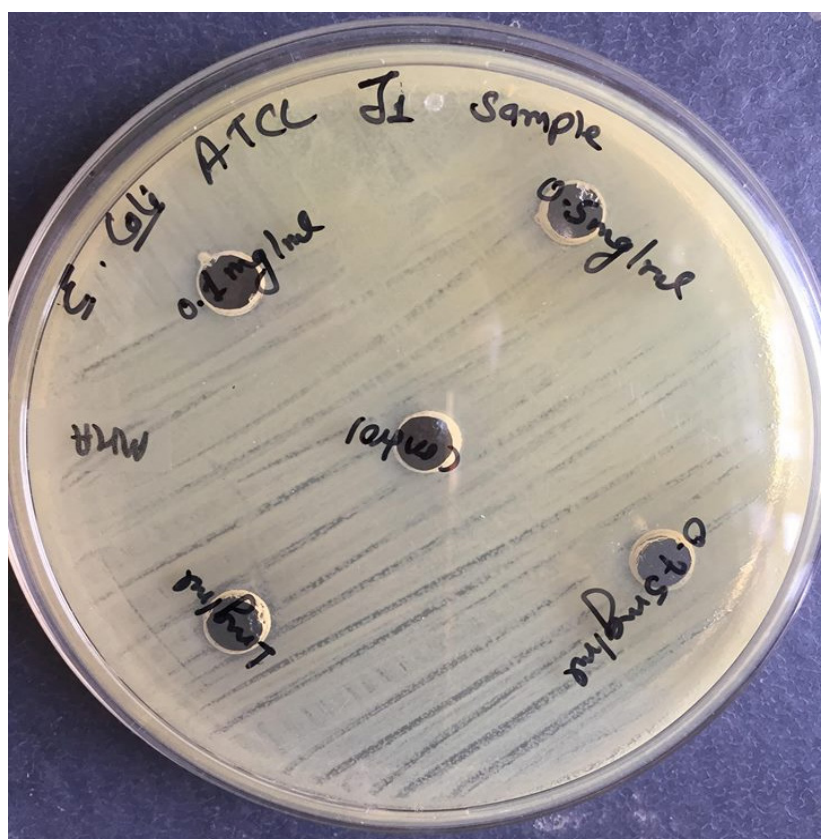

Figure 6: Antibacterial activities shown by $\mathrm{Cu}_{2} \mathrm{O} N \mathrm{NPS}_{\mathrm{S}}$ synthesized using $0.01 \mathrm{M} \mathrm{CuSO}_{4}$ and reducing agent $\mathrm{NaBH}_{4}$ in Escherichia coli.

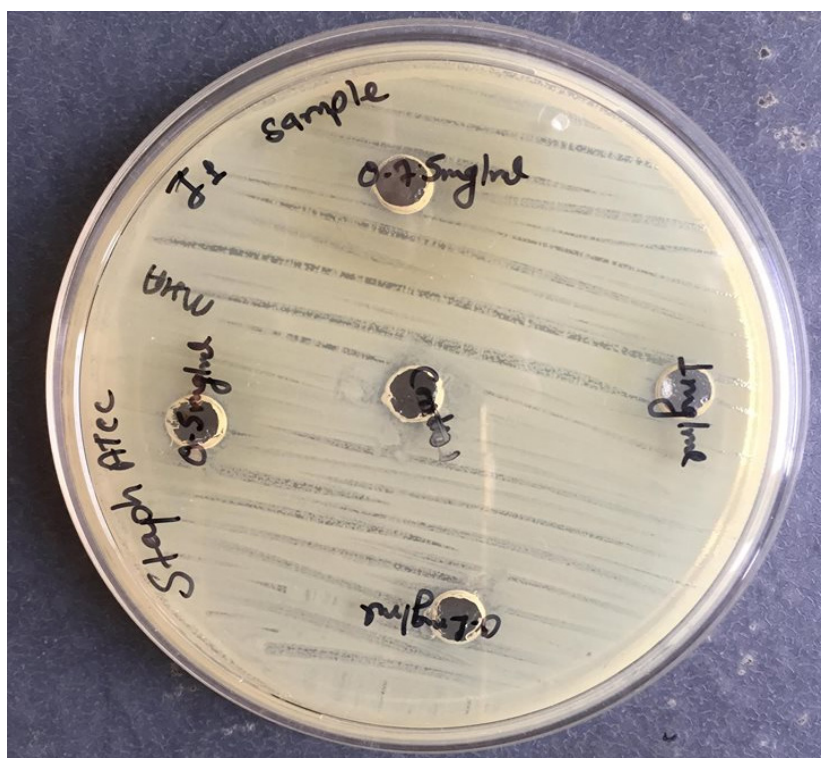

Figure 7: Antibacterial activities shown by $\mathrm{Cu}_{2} \mathrm{O} \mathrm{NPS}_{S}$ synthesized using $0.01 \mathrm{M} \mathrm{CuSO}_{4}$ and reducing agent $\mathrm{NaBH}_{4}$ in Staphylococcus aureus. 
Table 1: Comparison of antimicrobial activity of $\mathrm{Cu}_{2} \mathrm{O} N \mathrm{NS}_{\mathrm{S}}$ with standard antibiotics tetracycline [18]

\begin{tabular}{|c|c|c|c|c|c|}
\hline \multirow{2}{*}{ Pathogen } & \multicolumn{3}{|c|}{$\begin{array}{c}\text { Zone of inhibition (mm) } \\
\text { Concentration }(\mathbf{m g} / \mathbf{m l})\end{array}$} & $\begin{array}{c}\text { Standard Tetracycline } \\
\mathbf{( 5} \boldsymbol{\mu g} / \mathbf{d i s c})\end{array}$ \\
\cline { 2 - 5 } & 0.1 & 0.5 & 0.75 & 1 & \\
\hline Escherichia coli & 5 & 10 & 14 & 17 & 22 \\
Staphylococcus aureus & 7.5 & 13 & 17 & 19 & 22 \\
\hline
\end{tabular}

ions and radicals are responsible to injure cellular structure and disturb the physiological activity of microorganisms [7]. $\mathrm{Cu}_{2} \mathrm{O}$ NPs show that broadspectrum activity and antimicrobial activity increases with an increase in concentrations of the NPs. While comparing two different microorganisms, it is seen that the antibacterial activity of $\mathrm{Cu}_{2} \mathrm{O}$ NPs is more in Gram-positive ( $S$. aureus) bacteria than in Gramnegative bacteria.

\section{Conclusion}

$\mathrm{Cu}_{2} \mathrm{O}$ NPs have been synthesized successfully at two different concentration of copper precursors by the coprecipitation method using $\mathrm{NaBH}_{4}$ as a reducing agent and (PEG-6000) as a stabilizer. As the concentration of precursor increase from $0.01 \mathrm{M}$ to $0.1 \mathrm{M}$, the particle size of $\mathrm{Cu}_{2} \mathrm{O}$ also increases from $4.77 \mathrm{~nm}$ to $8.02 \mathrm{~nm}$. Morphology, particle size, and purity of synthesized $\mathrm{Cu}_{2} \mathrm{O}$ obtained from XRD, SAED, SEM, TEM, EDX, corroborate each other. Bactericidal activity of copper oxide performed on both Gram-positive and Gramnegative strain bacteria displays the effectiveness of $\mathrm{Cu}_{2} \mathrm{O}$ NPs against bacterial growth and antibacterial activity increases with increasing the concentration of copper oxide. Moreover, the antibacterial activity of $\mathrm{Cu}_{2} \mathrm{O}$ NPs was high for Gram-positive (Staphylococcus aureus) compare to Gram-negative (Escherichia coli) bacteria.

\section{Acknowledgments}

Authors are grateful to acknowledge the Department of Chemistry, Tri-Chandra Multiple Campus, and Central Department of Biotechnology, Tribhuvan University, Kathmandu, Nepal for providing lab facilities and necessary materials. We are also thankful to Indira Pokhrel, Center for Nanomaterials, Sogang University, Seoul, South Korea for SEM, SAED, TEM and EDX, and Dr. S. P. Singh, Research professor, Nanotechnology and Advanced Materials Engineering, Sejong University, Seoul, South Korea for XRD.

\section{References}

1. M. A. Khan, M. Ullah, T. Iqbal, H. Mahmood, A. A. Khan, M. Shafique, A. Majid, A. Ahmed and N. A. Khan, Surfactant assisted synthesis of cuprous oxide $\left(\mathrm{Cu}_{2} \mathrm{O}\right)$ nanoparticles via solvothermal process, Nanoscience and Nanotechnology Research, 2015, 3(1) 16-22. (DOI: 10.12691/nnr3-1-3).

2. S. S. Sawant, A. D. Bhagwat and C. M. Maharjan, Synthesis of cuprous oxide $\left(\mathrm{Cu}_{2} \mathrm{O}\right)$ nanoparticles - a review, Journal of Nano and Electronic Physics, 2016, 8(1), 1035-1040. (DOI:10.21272/ jnep.8(1).01035).

3. M. Bagherzadeha, N. Mousavi, M. Amini, S. Gautam, J. P. Singh and K. H. Chae, $\mathrm{Cu}_{2} \mathrm{O}$ nanocrystals with various morphology: synthesis, characterization and catalytic properties, Chinese Chemical Letters, 2017, 28, 1125-1130. (DOI:10.1016/j.cclet.2017.01.022).

4. P. Li, W. Lv and S. Ai, Green and gentle synthesis of $\mathrm{Cu}_{2} \mathrm{O}$ nanoparticles using lignin as reducing and capping reagent with antibacterial properties, Journal of Experimental Nanoscience, 2016, 11(1), 18-27. (DOI:10.1080/17458080.2015.101 5462).

5. Y. Qian, F. Ye, J. Xu, and Z. G. Le, Synthesis of cuprous oxide $\left(\mathrm{Cu}_{2} \mathrm{O}\right)$ nanoparticles/graphene composite with an excellent electrocatalytic activity towards glucose, International Journal of Electrochemical Science, 2012, 7, 10063-10073.

6. M. Behera, G. Giri, Green synthesis and characterization of cuprous oxide nanoparticles in presence of a bio-surfactant, Materials SciencePoland, 2014, 32(4), 702-708. (DOI:10.2478/ s13536-014-0255-4).

7. B. D. Du, D. V. Phu, L. A. Quoc and N. Q. Hien, Synthesis and investigation of antimicrobial 
activity of $\mathrm{Cu}_{2} \mathrm{O}$ nanoparticles/zeolite, Journal of Nanoparticles, 2017, 2017, 1-6. (DOI:10.1155/2017/7056864).

8. M. S. Usman, M. E. E. Zowalaty, K. Shameli, N. Zainuddin, M. Salama and N. A. Ibrahim, Synthesis, characterization, and antimicrobial properties of copper nanoparticles, International Journal of Nanomedicine, 2013, 8, 4467-4479.

9. K. Jhansi, S. Chandralingam, N. R. Manohar, P. Suvarna, C. Ashok and K. R. Venkateswara, $\mathrm{CuO}$ nanoparticles synthesis and characterization for humidity sensor application, Journal of Nanotechnology and Materials Science, 2016, 3(1), 10- 14. (DOI: 10.15436/2377-1372.16.020).

10. A. K. Chatterjee, R. Chakraborty and T. Basu, Mechanism of antibacterial activity of copper nanoparticles, Nanotechnology, 2014, 25, 135101-135113. (DOI:10.1088/09574484/25/13/135101).

11. J. Ramyadevi, K. Jeyasubramanian, A. Marikani, G. Rajakumar and A. A. Rahuman, Synthesis and antimicrobial activity of copper nanoparticles, Materials Letters, 2012, 71, 114-116.

12. A. Azam, A. Ahmed, M. Oves, M. Khan and A. Memic, Size dependent antimicrobial properties of $\mathrm{CuO}$ nanoparticles against gram positive and negative bacterial strains, International Journal of Nanomedicine, 2012, 7, 3527-3533.

13. N. A. Amro, L.P. Kotra, K. Wadu-Mesthrige, A. Bulychev, S. Mobashery and G. Y. Liu, High resolution atomic force microscopy studies of the $E$. coli outer membrane: structural basis for permeability, Langmuir, 2000, 16, 2789-2796.
14. I. Sondi, and B. Salopek-Sondi, Silver nanoparticles as antimicrobial agent: a case study on $E$. coli as a model for gram negative bacteria, Colloids, 2004, 275, 177-182. (DOI:10.1016/j. jcis.2004.02.012).

15. C. N. Lok, C. M. Ho, R. Chen, Q. Y. He, W.Y. Yu, H. Sun, P. K. Tam, J. F. Chiu and C. M. Che, Proteomic analysis of the mode of antibacterial action of silver nanoparticles, Journal of Proteome Research, 2006, 5, 916-924. (DOI 10.1007/ s00775-007-0208-z).

16. N. Ahmad, B. C. Ang, M. A. Amalina and C. W. Bong, Influence of precursor concentration and temperature on the formation of nanosilver in chemical reduction method, Sains Malaysiana, 2018, 47(1), 157-168.(DOI:10.17576/jsm-20184701-19).

17. N. Topnani, S. Kushwaha and T. Athar, Wet synthesis of copper oxide nanopowder, International Journal of Green Nanotechnology: Materials Science \& Engineering, 2010, 1(2), M67-M73. (DOI:10.1080/19430840903430220).

18. K. Muthulakshmi and C. Uma, Antimicrobial activity of Bacillus subtilis silver nanoparticles, Frontiers in Bioscience (Elite Ed.), 2019, 11, 89101. 